\title{
Genetic Variability and Direct Selection Criterion for Seed Yield in Segregating Generations of Barley (Hordeum vulgare L.)
}

\author{
Sunil K. Yadavi ${ }^{*}$, Ashok K. Singh1', Praveen Pandey², Smita Singh1 \\ ${ }^{1}$ Department of Genetics and Plant Breeding, Jawahar Lal Nehru Krishi Vishwavidyalaya, Rewa, India \\ ${ }^{2}$ Department of Genetics and Plant Breeding, Narendra Deva University of Agriculture and Technology, \\ Kumarganj, Faizabad, India \\ Email: "gentic.ksunil@ymail.com
}

Received 31 May 2015; accepted 22 June 2015; published 25 June 2015

Copyright (C) 2015 by authors and Scientific Research Publishing Inc.

This work is licensed under the Creative Commons Attribution International License (CC BY). http://creativecommons.org/licenses/by/4.0/

(c) (i) Open Access

\section{Abstract}

The aim of this study was to determine nature and extent of variability parameters and their utilization in barley breeding programme. A total of $45 F_{1} s$ along with their parents and $F_{2}$ populations were evaluated in a randomized block design with 3 replications during Rabi (winter season) 2014. The various traits measured were days to $50 \%$ flowering, days to maturity, plant height, flag leaf area, upper leaf area, tillers-plant, spikes-plant, spike length, grains ${ }^{- \text {spike, }}$ spike weight, grain

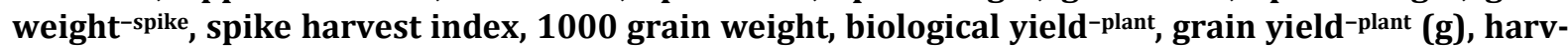
est index, grain size, husk content and protein content. Results showed that significant variation was observed for all the traits studied in the entire gene pool. The degree of genotypic and phenotypic coefficient of variation was high for tillers-plant, spike-plant, grain yield-plant, flag leaf area, harvest index, 1000 grain weight, grain weight-spike, upper leaf area and husk content. High herita-

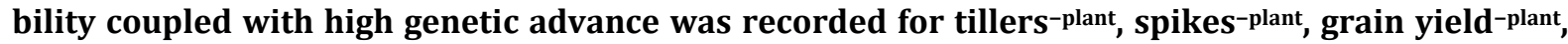
flag leaf area, harvest index, grain weight-spike, upper leaf area, husk content, grain size and plant height suggesting that these traits are highly heritable and governed by additive gene action. Moderate heritability coupled with high genetic advance was observed for 1000 grain weight, biological yield-plant, spike length, protein content, grains-spike and spike weight; however, days to $50 \%$ flowering and days to maturity had moderate heritability coupled with low genetic advance suggesting preponderance on non-additive gene action in the inheritance of these traits. It could be concluded that the traits of tillers-plant, spikes-plant, grain yield-plant, flag leaf area, harvest index, grain weight-spike, upper leaf area, husk content, grain size and plant height were identified as most decisive factor intended towards developing high yielding barley cultivars.

"Corresponding author.

How to cite this paper: Yadav, S.K., Singh, A.K., Pandey, P. and Singh, S. (2015) Genetic Variability and Direct Selection Criterion for Seed Yield in Segregating Generations of Barley (Hordeum vulgare L.). American Journal of Plant Sciences, 6, 1543-1549. http://dx.doi.org/10.4236/ajps.2015.69153 
Keywords

Barley, Genetic Variability, Heritability, Genetic Advance

\section{Introduction}

Barley (Hordeum vulgare L.), is a major cereal grain commonly used in malting and brewing industries. The cultivated barley is a self-pollinating, diploid species $2 n=2 x=14$ [1] and one of the first domesticated crops [2]. Barley is a renowned crop extensively grown under varying agro-climatic regions for food, feed and forage. It has superior nutritional qualities due to presence of beta-glucan (anti-cholesterol substance), acetylcholine carbohydrate substance which nourishes our nervous system and recovers memory loss, easy digestibility due to low gluten content and high lysine, thiamin and riboflavin render cooling effect in the body [3] [4]. Barley is a relatively drought tolerant crop and more tolerant of soil salinity than wheat. About $25 \%$ of the barley is used for malting, for which it is the best-suited grain. It is a key ingredient in beer and whisky production. Malting barley is usually lower protein which shows more uniform germination, needs shorter steeping, and has less protein in the extract that can make beer cloudy [5].

The plant breeders now have recognized the importance of utilizing genetic variability and diversity in breeding programmes to meet the continuously expanding needs of hybrid and varietal improvement. Although the assemblage, evolution and preservation of the entire germplasm are essential to more rewarding breeding efforts, a selection of most potential lines on biometrical analysis and on genetic-diversity is very essential for the success of breeding programmes and also for increasing the agricultural productivity.

Seed yield is very complex character whose manifestation results from multiplicative interactions of several quantitative traits and environmental factors [6]. The systematic breeding programme involves the steps like creating genetic variability practicing selection and utilization of selected genotypes to evolve promising varieties. Genetic improvement of crop is largely depending on the magnitude of genetic variability and the extent to which desirable traits are heritable. Considerably high magnitude of variability and high degree of transmission of the various yields and its associated traits have been repeatedly emphasized in barley germplasm [4] [7]-[21]. It is necessary to find out the relative magnitude of additive and non-additive genetic variances, heritability and genetic gain with regard to the characters of concern to the breeder. A major factor limiting the rate of progress in plant breeding has low heritability of quantitative traits such as yield. The most important function of the heritability in the genetic study is the predictive role to indicate the reliability of the phenotypic values as a guide to breeding value. Keeping in view, the present study has been undertaken to estimate genetic variability parameters which will play an important role in exploiting future research projections of barley improvement programme.

\section{Materials and Methods}

\subsection{Plant Material and Experimental Detail}

A total of $45 \mathrm{~F}_{1} \mathrm{~s}$ were synthesized in half diallel mating system involving ten barley genotypes (Table 1) and sufficient numbers of hand pollinated seeds were produced during winter season of 2012. Further, all the $F_{1} s$ were grown to raise $F_{2}$ seeds. The experimental material comprised with $45 F_{1}$ along with their $F_{2}$ populations and parents were evaluated in a randomized block design with 3 replications at Instructional farm of JNKVV, Rewa, India during winter season of 2014. The $\mathrm{F}_{1} \mathrm{~S}$ was grown in single row, parents in two rows and $\mathrm{F}_{2}$ populations in five rows of $3 \mathrm{~m}$ long bed with spacing of $25 \mathrm{~cm}$ between the rows. An approximate distance of $10 \mathrm{~cm}$ was maintained between plant to plant by hand thinning. The recommended agronomic practices were done timely to raise good crop stand.

\subsection{Traits Measurement}

The morphological data recorded on 10 randomly competitive plants from the middle row viz., days to 50\% flowering, days to maturity, plant height $(\mathrm{cm})$, flag leaf area $\left(\mathrm{cm}^{2}\right)$, upper leaf area $\left(\mathrm{cm}^{2}\right)$, tillers ${ }^{\text {-plant }}$, spikes ${ }^{\text {-plant }}$, spike length $(\mathrm{cm})$, grains ${ }^{\text {-spike }}$, spike weight $(\mathrm{g})$, grain weight ${ }^{- \text {spike }}(\mathrm{g})$, spike harvest index, 1000 grain weight $(\mathrm{g})$, 
Table 1. List of genotypes, parentage and their origin.

\begin{tabular}{cccc}
\hline S. No. & Variety & Parentage & Source/origin \\
\hline $\mathbf{1}$ & K508 & K394/K141 & C.S.A.U. \& T., KANPUR, U.P., India \\
$\mathbf{2}$ & JB 203 & JB58XRD2552 & J.N.K.V.V., REWA, M.P., India \\
$\mathbf{3}$ & RD2811 & RD2579/JB26/RD2552 & SKRAU, Durgapura, Rajasthan, India \\
$\mathbf{4}$ & RD2869 & RD2670/RD2508/RD2715 & C.S.A.U. \& T., KANPUR, U.P., India \\
$\mathbf{5}$ & HUB113 & KARAN280/C138 & B.H.U., VARANASI, U.P., India \\
$\mathbf{6}$ & JB1 & LAKHANXPL552 & J.N.K.V.V., REWA, M.P., India \\
$\mathbf{7}$ & RD2035 & RD103/PL101 & C.S.A.U. \& T., KANPUR, U.P., India \\
$\mathbf{8}$ & KB1201 & K560/K475 & C.S.A.U. \& T., KANPUR, U.P., India \\
$\mathbf{9}$ & LAKHAN & K12/IB226 & C.S.A.U. \& T., KANPUR, U.P., India \\
$\mathbf{1 0}$ & JYOTI & K12/C251 & C.S.A.U. \& T., KANPUR, U.P., India \\
\hline
\end{tabular}

biological yield ${ }^{\text {-plant }}(\mathrm{g})$, grain yield $\mathrm{d}^{\text {-plant }}(\mathrm{g})$, harvest index, grain size $\left(\mathrm{mm}^{2}\right)$, husk content $(\%)$ and protein content (\%).

\subsection{Statistical Analysis}

Data scored over morphological traits were subjected to statistical analyses for understanding the transmissibility of characters. The mean values were used to obtain analysis of variance as per methodology advocated by [22]. PCV and GCV were calculated by the formula given by [23], heritability in broad sense ( $\left.\mathrm{h}^{2}\right)$ by [24] and genetic advance were calculated by using the procedure given by [25].

\section{Results and Discussion}

\subsection{Analysis of Variance (ANOVA)}

The analysis of variance (Table 2) revealed highly significant difference for all the characters under study among the genotypes, indicating that the parents included in this investigation exhibit sufficient variability for the entire characters study. In the material under study maximum range of variability (Table 3) was observed for plant height (60.6 to $124.1 \mathrm{~cm})$, flag leaf area $\left(12.1\right.$ to $\left.47.1 \mathrm{~cm}^{2}\right)$, upper leaf area $\left(24.5\right.$ to $\left.79.5 \mathrm{~cm}^{2}\right)$, grains ${ }^{-s p i k e}$ (36.6 to 73.3 ), 1000 grain weight (22.7 to 81.3 g), biological yield ${ }^{\text {plant }}$ (47.08 to 104.8 g), harvest index (3.9\% to $63.6 \%$ ), grain size $\left(8.1\right.$ to $\left.65.7 \mathrm{~mm}^{2}\right)$, spike harvest index (51.1\% to $95.3 \%$ ) and days to $50 \%$ flowering (66.8 to 83.3 days). The characters showing high range of variation have more scope for improvement. All the characters under study exhibited high variability as evident from the ranges of mean values. The presence of large amount of variability might be due to diverse source of materials taken as well as environmental influence affecting the phenotypes. These findings are in consonance with the findings of earlier workers [4] [7]-[21].

\subsection{Genotypic and Phenotypic Coefficients of Variation}

Determination of genetic variability and partitioning it into heritable and non-heritable components using the genetic parameters viz., phenotypic and genotypic coefficients of variation, heritability and genetic advance is necessary to have an insight into genetic nature of yield and its components on which selection can be effectively carried out. Character like seed yield is complex in inheritance and is improved through its component traits. High yield can be achieved by selection of those yield contributing characters that have high heritability coupled with high genetic advance. Consequently, the components of variance and heritable components with genetic parameters are important to plan a suitable breeding strategy.

The estimates of phenotypic variability cannot differentiate between the effects of genotype and environment. Hence, the study of genetic variability is effective in partitioning out the real genetic differences. The estimates of GCV and PCV are of greater use in determining the variability present in the material. Generally, the magnitude 
Table 2. Analysis of variance (ANOVA) for various traits in barley.

\begin{tabular}{|c|c|c|c|c|}
\hline \multirow{2}{*}{ S.N. } & \multirow{2}{*}{ Character } & Replication & Genotypes & Error \\
\hline & & $(\mathrm{df}=02)$ & $(\mathrm{df}=54)$ & $(\mathrm{df}=108)$ \\
\hline 1 & Days to $50 \%$ flowering & 0.5 & $35.65^{* *}$ & 5.87 \\
\hline 2 & Days to maturity & 8.22 & $47.42^{* *}$ & 7.98 \\
\hline 3 & Plant height $\mathrm{cm}$ & 15.26 & $635.48^{* *}$ & 37.25 \\
\hline 4 & Flag leaf area $\left(\mathrm{cm}^{2}\right)$ & 0.44 & $237.74^{* *}$ & 12.74 \\
\hline 5 & Upper leaf area $\left(\mathrm{cm}^{2}\right)$ & 43.79 & $531.49^{* *}$ & 52.58 \\
\hline 6 & Tillers/ plant & 0.1 & $236.44^{* *}$ & 4.46 \\
\hline 7 & Spikes/plant & 3.68 & $146.77^{* *}$ & 5.56 \\
\hline 8 & Spike length $(\mathrm{cm})$ & 4.09 & $35.21^{* *}$ & 3.61 \\
\hline 9 & Grains/spike & 16.21 & $213.60^{* *}$ & 33.01 \\
\hline 10 & Spike weight (g) & 0.19 & $1.29^{* *}$ & 0.38 \\
\hline 11 & Grain weight/ spike (g) & 0.14 & $0.99^{* *}$ & 0.07 \\
\hline 12 & Spike harvest index & 91.07 & $371.28^{* *}$ & 109.33 \\
\hline 13 & 1000 grain weight (g) & 13.02 & $413.51^{* *}$ & 51.81 \\
\hline 14 & Biological yield/ plant (g) & 167.64 & $502.43^{* *}$ & 76.3 \\
\hline 15 & Grain yield/ plant (g) & 27.09 & $422.32^{* *}$ & 29.23 \\
\hline 16 & harvest index & 49.95 & $428.96^{* *}$ & 36.72 \\
\hline 17 & Grain size $\left(\mathrm{mm}^{2}\right)$ & 15.18 & $70.21^{* *}$ & 6.21 \\
\hline 18 & Husk content (\%) & 0.78 & $11.92^{* *}$ & 0.53 \\
\hline 19 & Protein content (\%) & 0.28 & $6.76^{* *}$ & 0.91 \\
\hline
\end{tabular}

*, ** Significant at $5 \%$ and $1 \%$ probability levels, respectively, d.f. = degree of freedom.

Table 3. Genetic variability parameters for different characters in barley.

\begin{tabular}{|c|c|c|c|c|c|c|c|c|c|}
\hline \multirow{2}{*}{ S.N. } & \multirow{2}{*}{ Character } & \multirow{2}{*}{ Mean } & \multirow{2}{*}{ SE } & \multicolumn{2}{|c|}{ Range } & \multirow{2}{*}{ GCV } & \multirow{2}{*}{ PCV } & \multirow{2}{*}{$h^{2}$ (BS) } & \multirow{2}{*}{ GA } \\
\hline & & & & Lowest & Highest & & & & \\
\hline 1 & Days to $50 \%$ flowering & 75.5 & 1.4 & 66.8 & 83.3 & 4.17 & 5.26 & 62.8 & 6.8 \\
\hline 2 & Days to maturity & 110.3 & 1.6 & 101.7 & 118.3 & 3.29 & 4.17 & 62.3 & 5.3 \\
\hline 3 & Plant height $\mathrm{cm}$ & 95.8 & 3.5 & 60.6 & 124.2 & 14.74 & 16.06 & 84.3 & 27.9 \\
\hline 4 & Flag leaf area $\left(\mathrm{cm}^{2}\right)$ & 28.2 & 2.1 & 12.1 & 47.1 & 30.72 & 33.22 & 85.5 & 58.5 \\
\hline 5 & Upper leaf area $\left(\mathrm{cm}^{2}\right)$ & 54.3 & 4.2 & 24.6 & 79.5 & 23.26 & 26.82 & 75.2 & 41.6 \\
\hline 6 & Tillers/ plant & 18.7 & 1.2 & 5.5 & 40.7 & 47.13 & 48.47 & 94.6 & 94.4 \\
\hline 7 & Spikes/plant & 16.8 & 1.4 & 7.7 & 33 & 40.94 & 43.29 & 89.4 & 79.8 \\
\hline 8 & Spike length (cm) & 19.9 & 1.1 & 12 & 25 & 16.32 & 18.91 & 74.5 & 29 \\
\hline 9 & Grains/spike & 51.9 & 3.3 & 36.7 & 73.3 & 14.94 & 18.59 & 64.6 & 24.7 \\
\hline 10 & Spike weight (g) & 3.3 & 0.4 & 1.6 & 4.9 & 16.73 & 24.96 & 44.9 & 23.1 \\
\hline 11 & Grain weight/spike (g) & 2.3 & 0.2 & 1 & 3.4 & 23.63 & 26.31 & 80.6 & 43.7 \\
\hline 12 & Spike harvest index & 71.9 & 6 & 51.1 & 95.3 & 13 & 19.51 & 44.4 & 17.8 \\
\hline 13 & 1000 grain weight (g) & 45.6 & 4.2 & 22.7 & 61.3 & 24.08 & 28.79 & 69.9 & 41.5 \\
\hline 14 & Biological yield/plant (g) & 66.7 & 5 & 47.8 & 104.8 & 17.87 & 22.15 & 65.1 & 29.7 \\
\hline 15 & Grain yield/plant (g) & 30.5 & 3.1 & 9.9 & 63.6 & 37.53 & 41.5 & 81.8 & 69.9 \\
\hline 16 & harvest index & 45.1 & 3.5 & 8.1 & 65.7 & 25.34 & 28.68 & 78.1 & 46.1 \\
\hline 17 & Grain size $\left(\mathrm{mm}^{2}\right)$ & 26.6 & 1.4 & 17.6 & 36.1 & 17.38 & 19.75 & 77.5 & 31.5 \\
\hline 18 & Husk content (\%) & 9.3 & 0.4 & 6.4 & 14 & 20.88 & 22.3 & 87.7 & 40.3 \\
\hline 19 & Protein content (\%) & 8.5 & 0.6 & 66.8 & 83.3 & 16.52 & 20.01 & 68.1 & 28.1 \\
\hline
\end{tabular}

*SE = Standard error, PCV = Phenotypic coefficient of variation, GCV = Genotypic coefficient of variation, $\mathrm{h}^{2}$ (BS) = Broad sense heritability, GA = Genetic advance. 
of phenotypic coefficient of variation was higher than the corresponding genotypic coefficient of variation for all the characters (Table 3) indicating that the apparent variation was not only due to genotype but also due to the favorable influence of environment and selection for these traits sometimes may be misleading. This environmental effect could be due to heterogeneity in soil fertility status and other unpredictable factors.

High degree of genotypic and phenotypic coefficient of variation $(>20 \%)$ were observed in case of tillers ${ }^{-p l a n t}$ $(47.13 \%, 48.47 \%)$ followed by spike ${ }^{\text {-plant }}(40.94 \%, 43.29 \%)$, grain yield ${ }^{\text {-plant }}(37.53 \%, 41.5 \%)$, flag leaf area (30.72\%, 33.22\%), harvest index (25.35\%, 28.68\%), 1000 grain weight $(24.08 \%, 28.79 \%)$, grain weight ${ }^{\text {spike }}$ (23.63\%, 26.31\%), upper leaf area $(23.26 \%, 26.82 \%)$, husk content $(20.88 \%, 22.3 \%)$ while; biological yield ${ }^{-p l a n t}$ (17.87\%, 22.15\%), spike weight (16.73\%, 24.96\%) and protein content (16.52\%, 20.01\%) had moderate GCV with high PCV suggesting that sufficient variability was present in the gene pool thus ample scope for genetic improvement through selection with these traits.

The moderate estimates $(>10 \%$ to $<20 \%)$ were recorded for spike length $(16.32 \%, 18.91 \%)$, grains ${ }^{\text {spike }}$ (14.94\%, 18.59\%), plant height (14.74\%, 16.06\%) and spike harvest index (13.00\%, 19.51\%). However, the low estimates of GCV and PCV were observed for days to $50 \%$ flowering $(4.17 \%, 5.26 \%)$ and days to maturity $(3.29 \%, 4.17 \%)$. The character possessing high genotypic coefficient of variation value has better scope of improvement through selection. The influence of environment on each trade could be determined on the basis of difference between phenotypic coefficient of variation and genotypic coefficient of variation. These findings were in close agreement with the findings of earlier workers [4] [11]-[21].

\subsection{Heritability and Genetic Advance}

These values alone are not helpful in determining the heritable portion of variation [26]. The proportion of genetic variability which is transmitted from parents to offspring is reflected by heritability [27]. In this context, the high estimates of heritability ( $>75 \%)$ was recorded by spike ${ }^{-p l a n t}(94.5 \%)$ followed by spike length (89.4\%), husk content (87.7\%), flag leaf area (85.4\%), plant height $(84.26 \%)$, grain yield ${ }^{\text {-plant }}(81.7 \%)$, grain weight $^{\text {-spike }}$ (80.6\%), harvest index (78.1\%), grain size (77.5\%) and upper leaf area (75.2\%). however spike length (74.5\%), 1000 grain weight $(69.9 \%)$, protein content $(68.2 \%)$, biological yield ${ }^{\text {-plant }}(65.1 \%)$, grains ${ }^{\text {-spike }}(64.6 \%)$, days to $50 \%$ flowering (62.8\%), days to maturity (62.3\%), spike weight (44.9\%) and spike harvest index (44.4\%) had moderate estimates. The characters with exhibited high heritability, suggested that the selection will be more effective. According to [28] such characters governed predominantly by additive gene action and could be improved through individual plant selection; whereas, low heritability indicated that the characters were highly influenced by environmental effect and genetic improvement through selection will be difficult due to effect of genotypes.

The genetic advance shows the improvement that can be made in a particular character by applying certain amount of selection intensity. The genotypic coefficient of variation $\mathrm{x}$ selection differential estimates the maximum effectiveness of selection and heritability indicates how closely the goal can be achieved. However, by increasing the genetic diversity, the expected genetic advance can still be increased. The character exhibiting high heritability may not necessarily to always give high genetic advance [25]. The highest value of genetic advance was shown by tillers ${ }^{-p l a n t}(94.4 \%)$, while days to maturity (5.30\%) had lowest value for this parameter. The characters exhibiting high estimates of genetic advance (>20\%) were spike ${ }^{-p l a n t}$ (79.8\%), grain yield-plant (69.9\%), flag leaf area (58.5\%), harvest index (46.1\%), grain weight ${ }^{\text {-spike }}(43.7 \%)$, upper leaf area (41.6\%), 1000 grain weight (41.5\%), husk content (40.3\%), grain size (31.5\%), biological yield-plant (29.7\%), spike length (29.0\%), protein content (28.1\%), plant height (27.9\%), grains-spike (24.7\%) and spike weight (23.1\%). The moderate estimate observed for spike harvest index (17.8\%) however, days to $50 \%$ flowering $(6.8 \%)$ and days to maturity (5.3\%) had low genetic advance.

It can be find out with greater degree of accuracy when heritability in conjunction with genetic advance is studied [29]. Thus a character possessing high heritability along with high genetic advance will be valuable in the selection programme. High heritability coupled with high genetic advance were recorded for tillers ${ }^{\text {-plant }}$, spikes $^{- \text {plant }}$, grain yield ${ }^{- \text {plant }}$, flag leaf area, harvest index, grain weight ${ }^{- \text {spike }}$, upper leaf area, husk content, grain size and plant height; suggesting preponderance of additive gene action in the expression of these characters. Therefore, selection may be effective through these characters in segregating generations for genetic improvement of barley.

Moderate heritability coupled with high genetic advance was observed for 1000 grain weight, biological 
yield $^{\text {-plant }}$, spike length, protein content, grains-spike and spike weight; while, spike harvest index had moderate estimates of both. However, days to $50 \%$ flowering and days to maturity had moderate heritability coupled with low genetic advance suggesting preponderance on non-additive gene action in the inheritance of these traits; hence in this case selection may not be effective. Most of the above results in respect to heritability and genetic advance are in agreement with earlier reports [4] [10]-[14] [16]-[20].

\section{Conclusion}

Barley is a renowned crop extensively grown under varying agro-climatic regions for food, feed and forage. Genetic improvement of any crop is largely depending on the magnitude of genetic variability and the extent to which desirable traits are heritable. In our study considerable variability was present in the entire gene pool. The degree of genotypic and phenotypic coefficient of variation was high for tillers ${ }^{\text {-plant }}$, spike ${ }^{\text {-plant }}$, grain yield ${ }^{\text {-plant }}$, flag leaf area, harvest index, 1000 grain weight, grain weight ${ }^{\text {-spike }}$, upper leaf area and husk content. High heritability coupled with high genetic advance was recorded for tillers ${ }^{-p l a n t}$, spikes ${ }^{- \text {plant }}$, grain yield ${ }^{\text {-plant }}$, flag leaf area, harvest index, grain weight ${ }^{- \text {spike }}$, upper leaf area, husk content, grain size and plant height suggesting that these traits are highly heritable and governed by additive gene action. The traits of viz., tillers ${ }^{-p l a n t}$, spikes ${ }^{\text {-plant }}$, grain yield $^{\text {-plant}}$, flag leaf area, harvest index, grain weight ${ }^{\text {-spike }}$, upper leaf area, husk content, grain size and plant height were identified as most important direct selection criterion intended at developing high yielding barley genotypes.

\section{References}

[1] Bennett, M.D. and Smith, L.B. (1976) Nuclear DNA Amounts in Angiosperms. Philosophical Transactions of the Royal Society (London) B Biological Sciences, 274, 227-274. http://dx.doi.org/10.1098/rstb.1976.0044

[2] Zohary, D. and Hopf, M. (2000) Domestication of Plants in the Old World: The Origin and Spread of Cultivated Plants in West Asia, Europe and the Nile Valley. Clarendon Press, Oxford.

[3] Behall, K.M., Scholfield, D.J. and Hallfrisch, J. (2004) Diets Containing Barley Significantly Reduce Lipids in Mildly Hypercholesterolemic Men and Women. American Journal of Clinical Nutrition, 80, 1185-1193.

[4] Kumar, M., Vishwakarma, S.R., Bhushan, B. and Kumar, A. (2013) Estimation of Genetic Parameters and Character Association in Barley (Hordeum vulgare L.). Journal of Wheat Research, 5, 76-78.

[5] McGee, H. (1986) On Food and Cooking: The Science and Lore of the Kitchen. Harper Collins Publishers Ltd., UK, 481.

[6] Grafius, J.E. (1959) Heterosis in Barley. Agronomy Journal, 51, 551-554. http://dx.doi.org/10.2134/agronj1959.00021962005100090013x

[7] Kumar, S., Prasad, L.C. and Kumar S. (2002) Variability and Correlation Studies in Barley. Research on Crops, 3, 432-436.

[8] El-Bawab, A.M.O. (2003) Genetic Studies on Some Characters in Barley. Egyptian Journal of Agricultural Research, 81, 581-593.

[9] Assefa, A. (2005) Biochemical and Morphological Variability among Barley Landraces. African Crop Science Journal, 13, 227-238.

[10] Wang, J., Zhou, M., Huang, Z., Lu, C. and Xu, R. (2006) Genetic Analysis of Quantitative Traits of a Doubled Haploid Population in Barley. Journal of Yang Zhou University (Agriculture and Life Sciences), 3, 65-69.

[11] Mishra, C.N., Singh, S.K., Singh, P.C., Bhardwaj, D.N. and Singh, H.L. (2007) Genetic Variability in Barley. International Journal of Plant Science, 3, 220-221.

[12] Singh, S.K., Sirchi, A., Kerkhi, A.S., Singh, O., Kumar, V., Singh, A., Singh, S.P. and Singh, R.P. (2008) Genetic Variability in Components for Grain Yield in Barley (Hordeum vulgare L.). Environment and Ecology, 26, $2379-2381$.

[13] Jalata, Z., Ayana, A. and Zeleke, H. (2011) Variability, Heritability and Genetic Advance for Some Yield and Yield Related Traits in Ethiopian Barley (Hordeum vulgare L.) Landraces and Crosses. Intenational Journal of Plant Breeding and Genetics, 5, 44-52. http://dx.doi.org/10.3923/ijpbg.2011.44.52

[14] Tazeen, M., Nadia, K. and Farzana, N.N. (2009) Heritability, Phenotypic Correlation and Path Coefficient Studies for Some Agronomic Characters in Synthetic Elite Lines of Wheat. Journal of Food Agriculture and Environoment, 7, 278-282.

http://world-food.net/heritability-phenotypic-correlation-and-path-coefficient-studies-for-some-agronomic-characters-i n-synthetic-elite-lines-of-wheat/ 
[15] Singh, A.P. (2011) Genetic Variability in Two-Rowed Barley (Hordeum vulgare L.). Indian Journal of Scientific and Research, 2, 21-23. http://indianjournals.com/ijor.aspx?target=ijor:ijsr1\&volume=2\&issue=3\&article=004

[16] Al-Tabbal, J.A. and Al-Fraihat, A.H. (2012) Genetic Variation, Heritability, Phenotypic and Genotypic Correlation Studies for Yield and Yield Components in Promising Barley Genotypes. Journal of Agriculture Science, 4, 193-210.

[17] Muhammad, R.W., Qayyum, A., Liaqat, S., Hamza, A., Yousaf, M.M., Ahmad, B., Shah, J., Hussain, M., Ahsan, A.N., Qurashi, S.H. and Noor, E. (2012) Variability, Heritability and Genetic Advance for Some Yield and Yield Related Traits in Barley (Hordeum vulgare L.) Genotypes in Arid Conditions. Journal of Food, Agriculture \& Environment, 10, 626-629. http://world-food.net/download/journals/2012-issue_3\&4/69.pdf

[18] Akanksha, Sirohi, A., Kumar, S., Kant, S., Pal, K., Kumar, A. and Singh, M. (2012) Genetic Improvement through Variability, Heritability and Genetic Advance in Barley Crop (Hordeum vulgare L.). Environment and Ecology, 30, 1343-1345.

[19] Dyulgerova, B. and Valcheva, D. (2014) Heritability, Variance Components and Genetic Advance of Yield and Some Yield Related Traits in Barley Doubled Haploid Lines. Turkish Journal of Agricultural and Natural Sciences, 1, 614-617.

[20] Addisu, A. and Shumet, T. (2015) Variability, Heritability and Genetic Advance for Some Yield and Yield Related Traits in Barley (Hordeum vulgare L.) Landraces in Ethiopia. Intenational Journal of Plant Breeding and Genetics, 9, 68-76. http://dx.doi.org/10.3923/ijpbg.2015.68.76

[21] Aynewa, Y., Dessalegn, T. and Bayu, W. (2015) Correlation and Genetic Variability Estimate of Malt Barley (Hordeum vulgare L.). International Journal of Advanced Research in Biological Sciences, 2, 79-85. http://www.ijarbs.com/pdfcopy/mar2015/ijarbs13.pdf

[22] Panse, V.G. and Shukhatme, P.V. (1967) Statistical Methods for Agricultural Workers. 2nd Edition, ICAR, New Delhi, 152-157.

[23] Burton, G.W. (1952) Quantitative Inheritance in Grasses. Proceeding of 6th International Grassland Congress, Vol. 1, Pennsylvania State College, 17-23 August 1952, 277-283.

[24] Burton, G.W. and de Vane, E.H. (1953) Estimating Heritability in Tall Fescue (Festuca arundincea) from Replicated Clonal Material. Agronomy Journal, 45, 474-481. http://dx.doi.org/10.2134/agronj1953.00021962004500100005x

[25] Johnson, H.W., Robinson, H.F. and Comstock, R.E. (1955) Estimates of Genetic and Environmental Variability in Soybeans. Agronomy Journal, 47, 314-318. http://dx.doi.org/10.2134/agronj1955.00021962004700070009x

[26] Falconer, D.S. (1960) Introduction to Quantitative Genetics. Oliver \& Boyd, Edinburgh, London, 380.

[27] Lush, J.L. (1949) Heritability of Quantitative Traits in Farm Animals. Proceeding of 8th International Congess on Genetics, Heriditas (Supplement), 35, 356-375. http://dx.doi.org/10.1111/j.1601-5223.1949.tb03347.x

[28] Panse, V.G. (1957) Genetics of Quantitative Characters in Relation to Plant Breeding. Indian Journal of Genetics and Plant Breeding, 28, 225-229.

[29] Dudly, J.W. and Moll, H. (1969) Interpretation and Use of Estimates of Heritability and Genetic Variance in Plant Breeding. Crop Science, 9, 257-267. http://dx.doi.org/10.2135/cropsci1969.0011183X000900030001x 